\title{
Control of Constipation in Patients Receiving CHOP or CHOP-Like Chemotherapy Regimens for Non-Hodgkin's Lymphoma
}

\author{
Hiroko Hayashi, ${ }^{a}$ Akio Suzuki, ${ }^{*}, a$ Koichi Ohata, ${ }^{a}$ Masashi Ishihara, ${ }^{a}$ Yushi Kubota, ${ }^{a}$ \\ Ryo Kobayashi, ${ }^{a}$ Yuhei Shibata, ${ }^{b}$ Hiroshi Nakamura, ${ }^{b}$ Nobuhiko Nakamura,${ }^{b}$ Junichi Kitagawa, ${ }^{b}$ \\ Hisashi Tsurumi, ${ }^{b}$ Masahito Shimizu, ${ }^{b}$ and Yoshinori Itoh ${ }^{a}$ \\ ${ }^{a}$ Department of Pharmacy, Gifu University Hospital; 1-1 Yanagido, Gifu 501-1194, Japan: and ${ }^{b}$ First Department of \\ Internal Medicine, Gifu University Graduate School of Medicine; 1-1 Yanagido, Gifu 501-1194, Japan. \\ Received December 20, 2016; accepted February 20, 2017
}

\begin{abstract}
Management of constipation in patients receiving cyclophosphamide, doxorubicin, vincristine and prednisolone (CHOP) or CHOP-like chemotherapy regimens is important for prevention of paralytic ileus. We reported earlier that the laxative action of magnesium oxide is reversed by the concomitant use of antacids in cancer patients receiving opioid analgesics. Here, we assessed the prevalence of prophylactic laxative medication for the control of constipation in patients receiving CHOP or CHOP-like regimens for non-Hodgkin's lymphoma. Data obtained from 211 eligible patients were retrospectively analyzed. Almost all patients (99\%) received anti-ulcer agents such as proton pump inhibitors and $\mathrm{H}_{2}$ receptor antagonists for the prophylaxis of gastric disorders associated with prednisolone. Prophylactic laxatives were prescribed in 86 patients $(\mathbf{4 0 . 8 \% )}$, in which magnesium oxide was used most predominantly (88.4\%). However, magnesium oxide at doses of $\leqq 2000 \mathrm{mg} / \mathrm{d}$ was not effective for prevention of constipation, although the compound totally inhibited the incidence of constipation at doses higher than $2000 \mathrm{mg} / \mathrm{d}$. Therefore, it is important to avoid negative drug interaction between magnesium oxide and antacids in patients receiving CHOP chemotherapy.
\end{abstract}

Key words laxative; magnesium oxide; antacid; constipation; non-Hodgkin's lymphoma

Vincristine, a microtubule assembly inhibitor, is a vinca alkaloid-type anticancer drug. ${ }^{1,2)}$ Vincristine-based regimens such as cyclophosphamide, doxorubicin, vincristine and prednisolone (CHOP) \pm rituximab (R-CHOP), clophosphamide, vincristine and prednisolone (CVP) \pm rituximab (R-CVP) and cyclophosphamide, pirarubicin, vincristine and prednisolone (THP-COP) \pm rituximab (R-THP-COP) are commonly used for the treatment of non-Hodgkin's lymphoma. ${ }^{3-6)}$ One of the most common adverse effects of these regimens is neurotoxicity associated with vincristine, which is characterized by the progressive degeneration of motor, sensory, and autonomic nerves. This neurotoxicity is a dose-limiting toxicity for vincristine. ${ }^{7)}$ In their retrospective analysis, Utsu et al. ${ }^{8)}$ demonstrated that a dose reduction in vincristine in patients receiving R-CHOP for diffuse large B cell lymphoma is associated with poor prognosis. ${ }^{8)}$ Therefore, prevention of vincristineinduced neurotoxicity is important to improve outcomes in patients with non-Hodgkin's lymphoma.

Previous studies show that constipation is a reliable indicator for paralytic ileus, one of symptoms of vincristine-induced neurotoxicity. ${ }^{9-11)}$ Paralytic ileus is a severe form of gastrointestinal toxicity and can lead to death in severe cases. ${ }^{9,12,13)}$ Control of defecation is important to prevent or ameliorate paralytic ileus, since constipation often precedes the occurrence of paralytic ileus. ${ }^{9-11)}$

However, the efficacy of routine prophylactic treatment with laxatives for prevention of constipation in patients with nonHodgkin's lymphoma receiving vincristine-based regimens has yet to be clarified.

In the present study, we retrospectively examined the prevalence of prophylactic treatment with laxatives and the incidence of constipation in patients receiving vincristinebased regimens such as $\mathrm{CHOP}$ or CHOP-like chemotherapy regimens for non-Hodgkin's lymphoma.

\section{MATERIALS AND METHODS}

Ethics Statement This study was carried out in accordance with the guidelines for human studies outlined by the ethics committee of the Gifu University Graduate School of Medicine (Institutional Review Board Approval No. 27-33), and notified by the Japanese government. In view of the retrospective nature of the study, the need for informed consent from subjects was not required.

Study Design and Patients A total of 244 patients with non-Hodgkin's lymphoma were admitted to Gifu University Hospital and received vincristine-based chemotherapy regimens between January 2012 and March 2015. Of these, we excluded 5 patients who were administered opioid analgesics, an agent that frequently causes constipation on its own, and 28 patients who received total parenteral nutrition, leaving 211 patients as eligible. Data on patient demographics, including comorbidity, clinical, laboratory and treatment data, were obtained from electronic medical records.

In the CHOP regimen, doxorubicin $\left(50 \mathrm{mg} / \mathrm{m}^{2}\right)$, vincristine $\left(1.4 \mathrm{mg} / \mathrm{m}^{2}\right.$, max. $\left.2.0 \mathrm{mg}\right)$ and cyclophosphamide $\left(750 \mathrm{mg} / \mathrm{m}^{2}\right)$ were injected on day 2; while prednisolone ( $100 \mathrm{mg} /$ body) was administered from day 2 to 6 . For R-CHOP, rituximab $\left(375 \mathrm{mg} / \mathrm{m}^{2}\right)$ was administered on day 1 . In the CVP regimen, vincristine $\left(1.4 \mathrm{mg} / \mathrm{m}^{2}\right.$, max. $\left.2.0 \mathrm{mg}\right)$ and cyclophosphamide $\left(750 \mathrm{mg} / \mathrm{m}^{2}\right)$ were injected on day 2 , and prednisolone $(100 \mathrm{mg} /$ body) was administered from day 2 to 6 . For R-CVP, rituximab $\left(375 \mathrm{mg} / \mathrm{m}^{2}\right)$ was administered on day 1 . In the THPCOP regimen, pirarubicin $\left(30 \mathrm{mg} / \mathrm{m}^{2}\right)$, vincristine $\left(1.0 \mathrm{mg} / \mathrm{m}^{2}\right.$, max. $2.0 \mathrm{mg})$ and cyclophosphamide $\left(500 \mathrm{mg} / \mathrm{m}^{2}\right)$ were injected on day 2 , and prednisolone $\left(30 \mathrm{mg} / \mathrm{m}^{2}\right)$ was administered from 
(A)

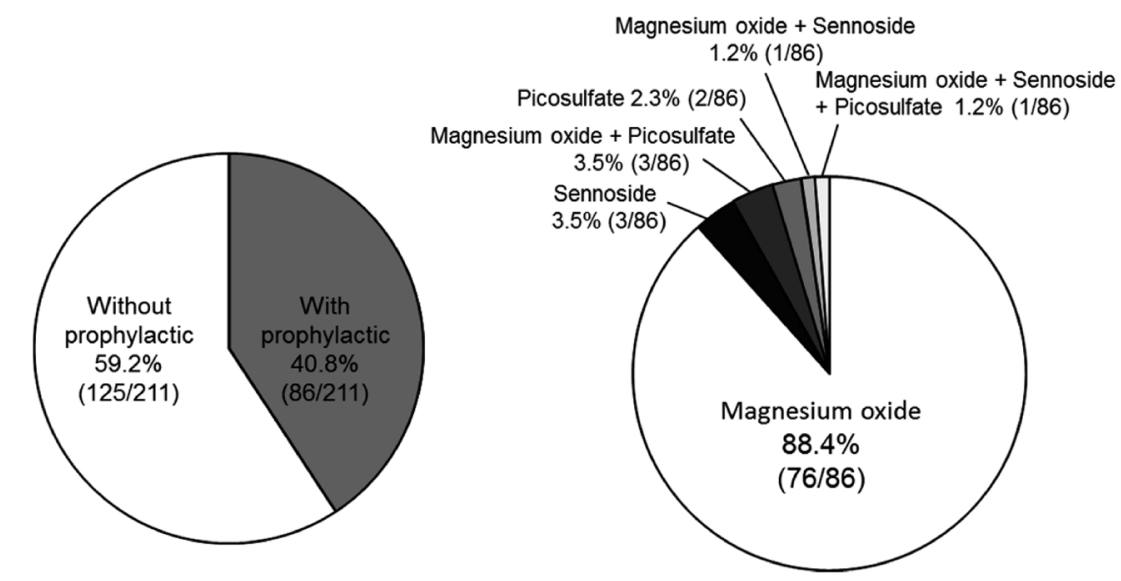

Fig. 1. Prevalence of Prophylactic Treatment with Laxatives (A) and Items of Laxatives (B) in Patients Receiving CHOP or CHOP-Like Chemotherapy Regimens for Non-Hodgkin's Lymphoma

day 2 to 6 . For R-THP-COP, rituximab $\left(375 \mathrm{mg} / \mathrm{m}^{2}\right)$ was injected on day 1 .

Evaluation of Constipation Constipation was defined as being stool-free for three consecutive days. The incidence of constipation was evaluated during the 10 -d period from the start of chemotherapy.

Data Analysis Data were analysed using SPSS version 22 (SPSS, Chicago, IL, U.S.A.). Parametric variables were analysed using the $t$-test, and non-parametric variables using the Mann-Whitney $U$ or chi-square test. Multiple comparison of non-parametric data was done using the Kruskal-Wallis test, and individual comparisons were done using Scheffe's test. $p$ Values less than 0.05 were considered statistically significant.

\section{RESULTS}

Patient Demographics Patient demographics are shown in Table 1. Among the 211 eligible patients, 209 (99\%) were administered proton pump inhibitors or histamine $\mathrm{H}_{2}$ receptor antagonists. The most common cancer type was diffuse large B cell lymphoma $(n=105,49.8 \%)$, followed by follicular lymphoma $(n=42,19.9 \%)$, mucosa associated lymphoid tissue lymphoma $(n=15,7.1 \%)$, peripheral $\mathrm{T}$ cell lymphoma $(n=11$, $5.2 \%)$, lymphoplasmacytic lymphoma $(n=5,2.4 \%)$, adult $\mathrm{T}$ cell leukemia-lymphoma $(n=5,2.4 \%)$, myelofibrosis $(n=4$, $1.9 \%)$, angioimmunoblastic $\mathrm{T}$ cell lymphoma $(n=3,1.4 \%)$, anaplastic large cell lymphoma $(n=3,1.4 \%)$, mantle cell lymphoma $(n=2,0.9 \%)$, and other cancer types $(n=16,7.7 \%)$. The most common chemotherapy regimen was R-CHOP $(n=128$, $60.7 \%)$, followed by CHOP $(n=32,15.2 \%)$, R-THP-COP $(n=30,14.2 \%)$, R-CVP $(n=12,5.7 \%)$, THP-COP $(n=8,3.8 \%)$, and CVP $(n=1,0.5 \%)$.

Eighty-six patients $(40.8 \%)$ were prescribed laxative treatment for the prophylaxis of constipation (Fig. 1A), of whom $76(88.4 \%)$ received magnesium oxide alone, 3 (3.5\%) received sennoside alone, 3 (3.5\%) received a combination of magnesium oxide and picosulfate, $2(2.3 \%)$ received picosulfate alone, $1(1.2 \%)$ received a combination of magnesium oxide and sennoside, and $1(1.2 \%)$ received a combination of sennoside and picosulfate (Fig. 1B).

Effect of Prophylactic Treatment with Laxatives on the Incidence of Constipation The incidence of constipation
Table 1. Patient Demographics

\begin{tabular}{|c|c|}
\hline Gender (male/female) & $113 / 98$ \\
\hline Age (range) & $62.50(16-86)$ \\
\hline Height, cm & $159.8 \pm 9.7$ \\
\hline Weight, kg & $55.8 \pm 11.2$ \\
\hline Body surface, $\mathrm{m}^{2}$ & $1.51 \pm 0.18$ \\
\hline Vincristine dose, $\mathrm{mg}$ & $1.8 \pm 0.8$ \\
\hline Use of antacid, $n(\%)$ & $209(99.1)$ \\
\hline Use of azole, $n(\%)$ & $193(91.5)$ \\
\hline Premedication of laxative agents, $n(\%)$ & $86(40.8)$ \\
\hline \multicolumn{2}{|l|}{ Diagnosis, $n(\%)$} \\
\hline Diffuse large B cell lymphoma & $105(49.8)$ \\
\hline Follicular lymphoma & $42(19.9)$ \\
\hline Mucosa associated lymphoid tissue lymphoma & $15(7.1)$ \\
\hline Peripheral $\mathrm{T}$ cell lymphoma & $11(5.2)$ \\
\hline Lymphoplasmacytic lymphoma & $5(2.4)$ \\
\hline Adult $\mathrm{T}$ cell leukemia-lymphoma & $5(2.4)$ \\
\hline Anaplastic large cell lymphoma & $3(1.4)$ \\
\hline Angioimmunoblastic $\mathrm{T}$ cell lymphoma & $3(1.4)$ \\
\hline Myelofibrosis & $4(1.9)$ \\
\hline Mantle cell lymphoma & $2(0.9)$ \\
\hline Other & $16(7.7)$ \\
\hline \multicolumn{2}{|l|}{ Chemotherapy regimen, $n(\%)$} \\
\hline $\mathrm{R}-\mathrm{CHOP}$ & $128(60.7)$ \\
\hline CHOP & $32(15.2)$ \\
\hline R-THP-COP & $30(14.2)$ \\
\hline R-CVP & $12(5.7)$ \\
\hline THP-COP & $8(3.8)$ \\
\hline CVP & $1(0.5)$ \\
\hline
\end{tabular}

did not significantly differ between patients who did and did not receive prophylactic laxatives $(30.2 \%$ versus $37.6 \%$, respectively, $p=0.269$ ) (Fig. 2A). Moreover, magnesium oxide at doses of $<2000 \mathrm{mg} / \mathrm{d}$ was not significantly effective for prevention of constipation, although the compound completely inhibited the incidence of constipation at doses of $>2000 \mathrm{mg} / \mathrm{d}$ (Fig. 2B).

Comparison of Characteristics between Patients with and without Constipation We subsequently compared the demographics between patients who showed constipation $(n=73)$ and those without constipation $(n=138)$. As shown in Table 2, there were no significant differences in demographics 
A)

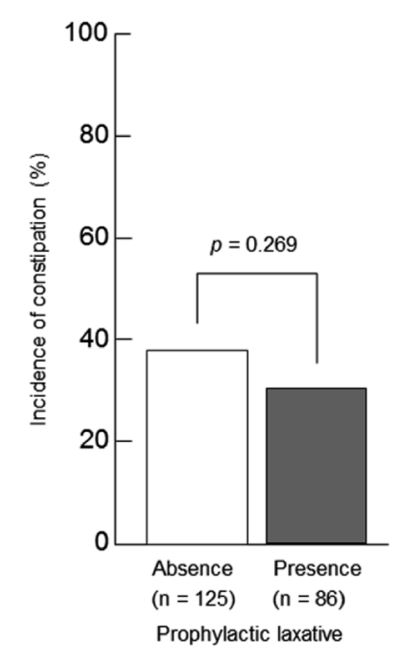

B)

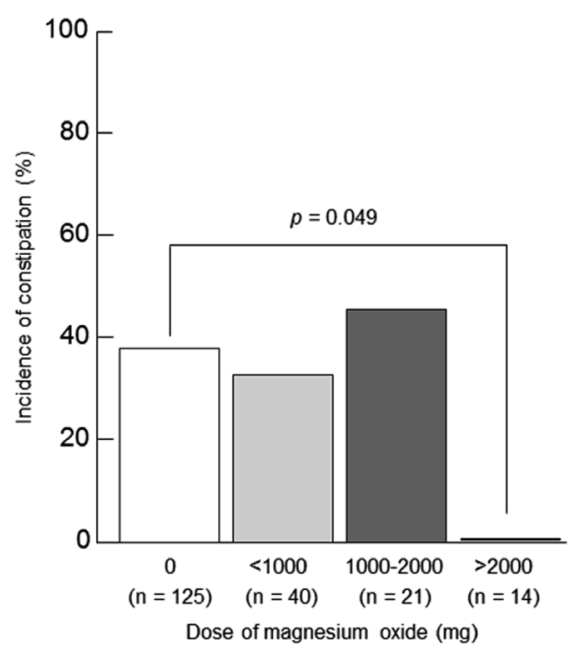

Fig. 2. Effect of Prophylactic Treatment with Laxatives (A) and the Effect of Various Doses of Magnesium Oxide (B) on the Incidence of Constipation in Patients Receiving CHOP or CHOP-Like Chemotherapy Regimens for Non-Hodgkin's Lymphoma

Data were statistically compared by chi-square test (A) or Kruskal-Wallis test followed by Scheffe's test (B).

between the two groups, except for the administration dose of magnesium oxide $(1155 \pm 338 \mathrm{mg} / \mathrm{d}$ versus $1387 \pm 575 \mathrm{mg} / \mathrm{d}$, mean \pm standard deviation, respectively, $p=0.028)$ and the number of patients who received high doses $(>1980 \mathrm{mg} / \mathrm{d})$ of magnesium oxide ( $0 \%$ versus $10.1 \%, p=0.005)$.

\section{DISCUSSION}

In this study, constipation was observed in $34.6 \%$ of patients receiving CHOP for non-Hodgkin's lymphoma. This incidence rate was similar to those reported previously, ${ }^{4,14-16)}$ in which the incidence of constipation for patients of all lymphoma grades was $38-41 \%$ for $\mathrm{CHOP} / \mathrm{R}-\mathrm{CHOP}^{4)} ; 29-30 \%$ for R-CHOP, R-CVP, and R-THO-COP ${ }^{14)}$; 43.5\% for $\mathrm{CHOP}^{15)}$; and $30 \%$ for R-CVP. ${ }^{16)}$

Most of our present patients (91.5\%) were treated with azole antifungal agents. Interestingly, previous reports indicate that itraconazole potentiates the neurotoxic effect of vincristine via the inhibition of vincristine metabolism by CYP3A4. ${ }^{17,18)}$ Therefore, the incidence of constipation or paralytic ileus may be influenced by combined treatment with azole antifungal agents such as itraconazole.

In contrast, prophylactic treatment with laxatives was prescribed to only $40.8 \%$ of patients receiving CHOP or CHOPlike regimens, among whom $88.4 \%$ patients received magnesium oxide alone. This prominent use of magnesium oxide is consistent with the findings of our previous multi-institutional study (619 patients from 35 institutions) of laxative pretreatment for prophylaxis of constipation in cancer patients receiving opioid analgesics, in which magnesium oxide was the most frequently prescribed laxative $(86.3 \%){ }^{19)}$

In the present study, prophylactic treatment with magnesium oxide at doses lower than $2000 \mathrm{mg} / \mathrm{d}$ had no significant effect on the incidence of constipation. This is in contrast to the findings of our previous study which showed that magnesium oxide at doses of $1000 \mathrm{mg} / \mathrm{d}$ and higher significantly prevented the constipation associated with opioid analgesics. ${ }^{19)}$ This discrepancy might be explained by the co-administration in the present study of magnesium oxide with antacids such as proton pump inhibitors and histamine $\mathrm{H}_{2}$ receptor antagonists, which were prescribed in almost all patients (99.1\%); specifically, protons are required for the laxative action of magnesium oxide, as shown by the following two equations:

$$
\text { Magnesium oxide }+2 \mathrm{HCl} \rightarrow \mathrm{MgCl}_{2}+\mathrm{H}_{2} \mathrm{O} \text { (in the stomach) }
$$

$$
\mathrm{MgCl}_{2}+2 \mathrm{NaHCO}_{3} \rightarrow \mathrm{Mg}\left(\mathrm{HCO}_{3}\right)_{2}+2 \mathrm{NaCl} \text { (in the duodenum) }
$$

The resulting formation of $\mathrm{Mg}\left(\mathrm{HCO}_{3}\right)_{2}$ increases osmotic pressure within the intestinal tract. ${ }^{20)} \mathrm{A}$ retrospective analysis by Yamasaki et al. $^{21)}$ reported that the effectiveness of magnesium oxide at controlling constipation after colon surgery or total gastric resection was significantly worse in patients taking antacids than in those who were not. We also recently reported that antacids, including proton pump inhibitors and $\mathrm{H}_{2}$ receptor antagonists, significantly impair the laxative actions of magnesium oxide at doses lower than $2000 \mathrm{mg} / \mathrm{d}$, but not at $2000 \mathrm{mg} / \mathrm{d}$ and higher, in cancer patients receiving opioid analgesics. ${ }^{22)}$ Interestingly, in the present study, magnesium oxide at $2000 \mathrm{mg} / \mathrm{d}$ and higher did completely inhibit the incidence of constipation. Taken together, the laxative actions of magnesium oxide at doses lower than $2000 \mathrm{mg} / \mathrm{d}$, but not at $2000 \mathrm{mg} / \mathrm{d}$ and higher, may be predominantly dependent on the gastric $\mathrm{pH}$.

Other mechanisms may function at higher doses of magnesium oxide. Previous reports indicate that cholecystokinin and constitutive nitric oxide synthase are involved in the laxative actions of magnesium sulfate. ${ }^{23}$ Interestingly, $\mathrm{Vu}$ et $a .^{24)}$ reported that magnesium sulfate administered in combination with a fatty meal causes diarrhea by elevating levels of postprandial plasma peptide YY and cholecystokinin. Furthermore, Ikarashi et al. ${ }^{25)}$ showed in rats that magnesium concomitantly increases the expression of aquaporin 3 in mucosal epithelial cells at the onset of diarrhea. Therefore, higher doses of magnesium oxide ( $\geqq 2000 \mathrm{mg} / \mathrm{d}$ ) may be required to sufficiently control constipation in patients receiving $\mathrm{H}_{2}$ recep- 
Table 2. Comparison of Characteristics between Patients with and without Constipation after CHOP or CHOP-Like Chemotherapy Treatment

\begin{tabular}{|c|c|c|c|}
\hline & With constipation $(N=73)$ & Without constipation $(N=138)$ & $p$ Value \\
\hline Gender (male/female) & $36 / 37$ & $77 / 61$ & $0.369^{a)}$ \\
\hline Age, (range) & $64.5(16-86)$ & $60.7(19-84)$ & $0.066^{b)}$ \\
\hline Height, cm & $159.0 \pm 9.1$ & $160.2 \pm 10.1$ & $0.973^{c)}$ \\
\hline Weight, $\mathrm{kg}$ & $55.2 \pm 11.6$ & $56.2 \pm 11.1$ & $0.561^{c)}$ \\
\hline Body surface, $\mathrm{m}^{2}$ & $1.50 \pm 0.18$ & $1.51 \pm 0.18$ & $0.578^{c)}$ \\
\hline Aspartate transaminase, IU/L & $30.1 \pm 25.1$ & $33.0 \pm 50.1$ & $0.642^{c)}$ \\
\hline Alanine aminotransferase, IU/L & $27.8 \pm 28.7$ & $29.3 \pm 54.6$ & $0.819^{c)}$ \\
\hline Serum creatinine, $\mathrm{mg} / \mathrm{dL}$ & $0.74 \pm 0.31$ & $0.71 \pm 0.23$ & $0.425^{c)}$ \\
\hline White blood cells, $/ \mathrm{mL}$ & $6618.2 \pm 7783.7$ & $6444.4 \pm 8190.5$ & $0.882^{c)}$ \\
\hline Hemoglobin, g/dL & $11.5 \pm 2.1$ & $11.8 \pm 2.2$ & $0.407^{c)}$ \\
\hline Blood platelet count, $\mathrm{g} / \mathrm{dL}$ & $18.3 \pm 9.5$ & $20.2 \pm 8.4$ & $0.138^{c}$ \\
\hline Vincristine dose, $\mathrm{mg}$ & $1.8 \pm 0.3$ & $1.8 \pm 0.3$ & $0.578^{a)}$ \\
\hline Use of antacid, $n(\%)$ & $72(98.6)$ & $137(99.3)$ & $0.645^{a)}$ \\
\hline Use of itraconazole, $n(\%)$ & $4(5.5)$ & $15(10.9)$ & $0.694^{a)}$ \\
\hline Premedication of laxative agents, $n(\%)$ & $26(35.6)$ & $60(43.5)$ & $0.269^{a)}$ \\
\hline Dose of magnesium oxide, $\mathrm{mg}$ & $1155.0 \pm 337.7$ & $1387.3 \pm 574.6$ & $0.028^{b)}$ \\
\hline \multicolumn{4}{|l|}{ Dose of magnesium oxide, $n(\%)$} \\
\hline$<1000 \mathrm{mg}$ & $13(17.8)$ & $27(19.6)$ & $0.757^{a)}$ \\
\hline $1000 \mathrm{mg} \leq>1500 \mathrm{mg}$ & $1(1.4)$ & $1(0.7)$ & $0.645^{a)}$ \\
\hline $1500 \mathrm{mg} \leq>1980 \mathrm{mg}$ & $10(13.7)$ & $10(7.2)$ & $0.128^{a)}$ \\
\hline$>1980 \mathrm{mg}$ & 0 & $14(10.1)$ & $0.005^{a)}$ \\
\hline \multicolumn{4}{|l|}{ Diagnosis, $n(\%)$} \\
\hline Diffuse large B cell lymphoma & $41(56.2)$ & $66(47.8)$ & $0.824^{d)}$ \\
\hline Follicular lymphoma & $13(17.8)$ & $29(21.0)$ & \\
\hline Mucosa associated lymphoid tissue lymphoma & $6(8.2)$ & $9(6.5)$ & \\
\hline Peripheral $\mathrm{T}$ cell lymphoma & $2(2.7)$ & $9(6.5)$ & \\
\hline Lymphoplasmacytic lymphoma & $2(2.7)$ & $3(2.2)$ & \\
\hline Adult T cell leukemia-lymphoma & $1(1.4)$ & $4(2.9)$ & \\
\hline Anaplastic large cell lymphoma & $1(1.4)$ & $2(1.4)$ & \\
\hline Angioimmunoblastic $\mathrm{T}$ cell lymphoma & $1(1.4)$ & $2(1.4)$ & \\
\hline Myelofibrosis & 0 & $4(2.9)$ & \\
\hline Mantle cell lymphoma & 0 & $2(1.4)$ & \\
\hline Other & $6(8.2)$ & $8(5.8)$ & \\
\hline \multicolumn{4}{|l|}{ Chemotherapy regimen, $n(\%)$} \\
\hline R-CHOP & $40(54.8)$ & $85(61.6)$ & $0.423^{d)}$ \\
\hline $\mathrm{CHOP}$ & $12(16.4)$ & $20(14.5)$ & \\
\hline R-THP-COP & $14(19.2)$ & $16(11.6)$ & \\
\hline THP-COP & $1(1.4)$ & $7(5.1)$ & \\
\hline $\mathrm{R}-\mathrm{CVP}$ & $5(6.8)$ & $7(5.1)$ & \\
\hline CVP & 0 & $1(0.7)$ & \\
\hline
\end{tabular}

Data are mean (S.D.) unless otherwise specified. a) Chi-square test. $b$ ) Mann-Whitney $U$-test. $c$ ) Unpaired $t$-test. $d$ ) Mxn chi-square test.

tor antagonists or proton pump inhibitors.

It is important to note that high doses of magnesium oxide increase the risk of hypermagnesemia in elderly patients and in those with renal disturbances. ${ }^{26,27)}$ Previous studies indicate that hypermagnesemia onset is dose-dependent. ${ }^{28)}$ It is a rare but severe side effect of magnesium oxide intake, with symptoms such as nausea/vomiting, hypotension, bradycardia, and muscle weakness in the early stages; and respiratory depression, arrhythmia, consciousness disturbances, and cardiac arrest in severe cases. Moreover, a case report showed that hypermagnesemia can occur at lower doses $(1000 \mathrm{mg} / \mathrm{d})$ of magnesium oxide in women with a history of coronary artery bypass surgery, hypertension, and diabetes mellitus. ${ }^{29)}$

In our present study, there were no significant differences in demographics between patients who presented with and without constipation, except for the administered dose of magnesium oxide, indicating that pretreatment with high doses of magnesium oxide was the only factor that reduced the incidence of constipation associated with CHOP or CHOP-like chemotherapy.

Several limitations of the present study warrant mention. The study was conducted under a retrospective design at a single medical institution and with a small sample size. In addition, the prophylactic effect of laxative agents other than magnesium oxide could not be sufficiently analyzed. Confirmation of our results therefore requires a large-scale, multiinstitutional prospective study.

In conclusion, we reported the incidence and control of constipation in patients receiving CHOP or CHOP-like chemotherapy regimens for non-Hodgkin's lymphoma. Antacids such as proton pump inhibitors and $\mathrm{H}_{2}$ receptor antagonists were prescribed to almost all patients. Prophylactic treatment with laxatives, consisting predominantly of magnesium oxide alone, had no significant effect on the incidence of constipation, but 
magnesium oxide doses of $2000 \mathrm{mg} / \mathrm{d}$ and higher prevented constipation. To avoid drug interaction between laxatives and antacids, and to avoid hypermagnesemia, other laxative agents with different modes of action should be administered to prevent the constipation associated with vincristine.

Conflict of Interest The authors declare no conflict of interest.

\section{REFERENCES}

1) Levêque D, Jehl F. Molecular pharmacokinetics of catharanthus (vinca) alkaloids. J. Clin. Pharmacol., 47, 579-588 (2007).

2) Owellen RJ, Hartke CA, Dickerson RM, Hains FO. Inhibition of tubulin-microtubule polymerization by drugs of the vinca alkaloid class. Cancer Res., 36, 1499-1502 (1976).

3) Fisher RI, Gaynor ER, Dahlberg S, Oken MM, Grogan TM, Mize EM, Glick JH, Coltman CA Jr, Miller TP. Comparison of a standard regimen (CHOP) with three intensive chemotherapy regimens for advanced non-Hodgkin's lymphoma. N. Engl. J. Med., 328, 10021006 (1993).

4) Coiffier B, Lepage E, Briere J, Herbrecht R, Tilly H, Bouabdallah R, Morel P, Van Den Neste E, Salles G, Gaulard P, Reyes F, Lederlin P, Gisselbrecht C. CHOP chemotherapy plus rituximab compared with CHOP alone in elderly patients with diffuse large-B-cell lymphoma. N. Engl. J. Med., 346, 235-242 (2002).

5) Marcus R, Imrie K, Belch A, Cunningham D, Flores E, Catalano J, Solal-Celigny P, Offner F, Walewski J, Raposo J, Jack A, Smith P. CVP chemotherapy plus rituximab compared with CVP as first-line treatment for advanced follicular lymphoma. Blood, 105, 1417-1423 (2005).

6) Kasahara S, Hara T, Tsurumi H, Goto N, Kitagawa J, Kanemura N, Yoshikawa T, Goto H, Fukuno K, Yamada T, Sawada M, Takahashi T, Takami T, Moriwaki H. Phase II study of the tetrahydropyranyl adriamycin-cyclophosphamide, vincristine, and prednisolone regimen combined with rituximab as first-line treatment for elderly patients with diffuse large B-cell lymphoma. Leuk. Lymphoma, 52, 629-634 (2011)

7) Windebank AJ, Grisold W. Chemotherapy-induced neuropathy. $J$. Peripher. Nerv. Syst., 13, 27-46 (2008).

8) Utsu Y, Takaishi K, Inagaki S, Arai H, Yuasa H, Masuda S, Matsuura $\mathrm{Y}$, Aotsuka N, Wakita $\mathrm{H}$. Influence of dose reduction of vincristine in R-CHOP on outcomes of diffuse large B cell lymphoma. Ann. Hematol., 95, 41-47 (2016).

9) Toghill PJ, Burke JD. Death from paralytic ileus following vincristine therapy. Postgrad. Med. J., 46, 330-331 (1970).

10) Shaw RK, Bruner JA. Clinical evaluation of vincristine (M.S.C.-67574). Cancer Chemother. Rep., 42, 45-48 (1964).

11) Martin J, Compston N. Vincristine sulphate in the treatment of lymphoma and leukaemia. Lancet, 282, 1080-1083 (1963).

12) Yasu T, Ohno N, Kawamata T, Kurokawa Y. Vincristine-induced paralytic ileus during induction therapy of treatment protocols for acute lymphoblastic leukemia in adult patients. Int. J. Clin. Pharmacol. Ther., 54, 471-473 (2016).

13) Legha SS. Vincristine neurotoxicity. Pathophysiology and management. Med. Toxicol., 1, 421-427 (1986).

14) Okada N, Hanafusa T, Sakurada T, Teraoka K, Kujime T, Abe M, Shinohara Y, Kawazoe K, Minakuchi K. Risk factors for earlyonset peripheral neuropathy caused by vincristine in patients with a first administration of R-CHOP or R-CHOP-like chemotherapy. $J$. Clin. Med. Res., 6, 252-260 (2014).

15) Kagami Y, Itoh K, Tobinai K, Fukuda H, Mukai K, Chou T, Mikuni C, Kinoshita T, Fukushima N, Kiyama Y, Suzuki T, Sasaki T, Watanabe Y, Tsukasaki K, Hotta T, Shimoyama M, Ogura M, Lymphoma Study Group of the Japan Clinical Oncology Group. Phase II study of cyclophosphamide, doxorubicin, vincristine, prednisolone (CHOP) therapy for newly diagnosed patients with low- and lowintermediate risk, aggressive non-Hodgkin's lymphoma: final results of the Japan Clinical Oncology Group Study, JCOG9508. Int. J. Hematol., 96, 74-83 (2012).

16) Kang HJ, Kim WS, Kim SJ, Lee JJ, Yang DH, Kim JS, Lee SR, Lee GW, Kim HJ, Kim HY, Oh SY, Kim HC, Eom HS, Chung J, Park J, Suh C, Ryoo BY. Phase II trial of rituximab plus CVP combination chemotherapy for advanced stage marginal zone lymphoma as a first-line therapy: Consortium for Improving Survival of Lymphoma (CISL) study. Ann. Hematol., 91, 543-551 (2012).

17) Ocean AJ, Vahdat LT. Chemotherapy-induced peripheral neuropathy: pathogenesis and emerging therapies. Support. Care Cancer, 12, 619-625 (2004).

18) Bermúdez M, Fuster JL, Llinares E, Galera A, Gonzalez C. Itraconazole-related increased vincristine neurotoxicity: case report and review of literature. J. Pediatr. Hematol. Oncol., 27, 389-392 (2005).

19) Ishihara M, Ikesue $\mathrm{H}$, Matsunaga $\mathrm{H}$, Suemaru K, Kitaichi K, Suetsugu K, Oishi R, Sendo T, Araki H, Itoh Y, Japanese Study Group for the Relief of Opioid-induced Gastrointestinal Dysfunction. A multi-institutional study analyzing effect of prophylactic medication for prevention of opioid-induced gastrointestinal dysfunction. Clin. J. Pain, 28, 373-381 (2012).

20) Lindberg JS, Zobitz MM, Poindexter JR, Pak CY. Magnesium bioavailability from magnesium citrate and magnesium oxide. J. Am. Coll. Nutr., 9, 48-55 (1990).

21) Yamasaki M, Funakoshi S, Matsuda S, Imazu T, Takeda Y, Murakami $T$, Maeda Y. Interaction of magnesium oxide with gastric acid secretion inhibitors in clinical pharmacotherapy. Eur. J. Clin. Pharmacol., 70, 921-924 (2014).

22) Ibuka $H$, Ishihara M, Suzuki $A$, Kagaya H, Shimizu M, Kinosada Y, Itoh Y. Antacid attenuates the laxative action of magnesia in cancer patients receiving opioid analgesic. J. Pharm. Pharmacol., 68, 1214-1221 (2016).

23) Izzo AA, Gaginella TS, Mascolo N, Capasso F. Nitric oxide as a mediator of the laxative action of magnesium sulphate. Br. J. Pharmacol., 113, 228-232 (1994).

24) $\mathrm{Vu}$ MK, Nouwens MA, Biemond I, Lamers CB, Masclee AA. The osmotic laxative magnesium sulphate activates the ileal brake. Aliment. Pharmacol. Ther., 14, 587-595 (2000).

25) Ikarashi N, Ushiki T, Mochizuki T, Toda T, Kudo T, Baba K, Ishii M, Ito K, Ochiai W, Sugiyama K. Effects of magnesium sulphate administration on aquaporin 3 in rat gastrointestinal tract. Biol. Pharm. Bull., 34, 238-242 (2011).

26) Weisinger JR, Bellorin-Font E. Magnesium and phosphorus. Lancet, 352, 391-396 (1998).

27) Onishi S, Yoshino S. Catharticinduced fatal hypermagnesemia in the elderly. Intern. Med., 45, 207-210 (2006).

28) Saito N. Influence of impaired renal function and magnesium oxide administration on serum magnesium levels in elderly inpatients. Nippon Ronen Igakkai Zasshi, 48, 263-270 (2011).

29) Weng YM, Chen SY, Chen HC, Yu JH, Wang SH. Hypermagnesemia in a constipated female. J. Emerg. Med., 44, e57-e60 (2013). 